\title{
High prevalence of right to left shunt in women with chronic migraine
}

\author{
D Larrosa*, L Benavente, S Calleja, M Gonzalez-Delgado, J Pascual \\ From The European Headache and Migraine Trust International Congress \\ London, UK. 20-23 September 2012
}

\section{Introduction}

Prevalence of right to left shunt is estimated as $25 \%$ of the general population [1]. The prevalence of shunt has been shown to be increased in migraine with aura and one study has found a high prevalence of shunt in chronic migraine $(\mathrm{CM})[2]$.

\section{Objectives}

To study the prevalence of right to left shunt in a series of women with CM.

\section{Methods}

This series includes 51 women (age 44 years, range 16-63) meeting diagnostic criteria (IHC-II revised 2006)for $\mathrm{CM}$. There were only 5 women with migraine with aura attacks. We carried out a transcranial doppler study (AplioXG, model SSA-790A, Toshiba) following the CODICIA study protocol [3].

\section{Results}

Thirty patients $(58.8 \%)$ showed some degree of right to left shunt. Three $(60 \%)$ out of the 5 patients with migraine with aura had shunt. Thirteen patients $(43 \%$, 25 of total series) had hits during normal breathing and 17 (58\%, 33\% of the total series) during Valsalva maneuver. Shunt was massive in 10 patients $(33 \%, 20 \%$ of the total series); in 9 of them shunt became massive only during the Valsalva maneuver.

\section{Conclusions}

Prevalence of right to left shunt in women with $\mathrm{CM}$ is higher than expected for the general population (1). The clinical implications of our findings need to be determined, though they suggest a relationship between the presence of shunt with an increased frequency of migraine attacks.

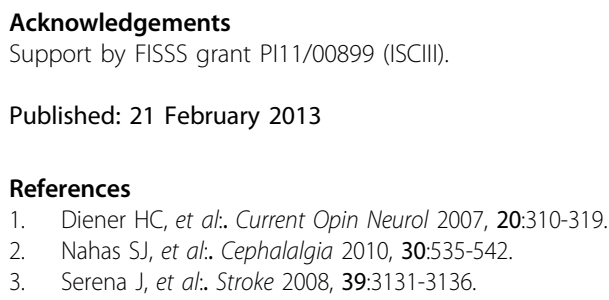

Acknowledgements

Support by FISSS grant PI11/00899 (ISCIII).

Published: 21 February 2013

References

1. Diener HC, et al:. Current Opin Neurol 2007, 20:310-319.

2. Nahas SJ, et al:. Cephalalgia 2010, 30:535-542.

3. Serena J, et al:. Stroke 2008, 39:3131-3136.

doi:10.1186/1129-2377-14-S1-P105

Cite this article as: Larrosa et al:: High prevalence of right to left shunt in women with chronic migraine. The Journal of Headache and Pain 2013 14(Suppl 1):P105.
Submit your manuscript to a SpringerOpen ${ }^{\bullet}$ journal and benefit from:

- Convenient online submission

- Rigorous peer review

- Immediate publication on acceptance

Open access: articles freely available online

- High visibility within the field

- Retaining the copyright to your article
(C) 2013 Larrosa et al; licensee Springer. This is an Open Access article distributed under the terms of the Creative Commons Attribution License (http://creativecommons.org/licenses/by/2.0), which permits unrestricted use, distribution, and reproduction in any medium, provided the original work is properly cited. 